\title{
Intraspecific food competition in the deposit-feeding benthic amphipod Monoporeia affinis- a laboratory study
}

\author{
Ragnar Elmgren ${ }^{1, *}$, Gunilla Ejdung ${ }^{1}$, Sven Ankar ${ }^{2, * *}$ \\ ${ }^{1}$ Department of Systems Ecology and ${ }^{2}$ Askö Laboratory, Stockholm University, 10691 Stockholm, Sweden
}

\begin{abstract}
Field studies in the Baltic Sea indicate that the growth rate of the deposit-feeding benthic amphipod Monoporeia affinis (Lindström), which is found in densities of up to $\cong 25000$ ind. $\mathrm{m}^{-2}$, is negatively density-dependent. We tested the density-dependence of growth in $M$. affinis under controlled laboratory conditions, using sediment of high organic content (loss on ignition 10.9\%) and a wide density range of 2 amphipod year-classes (juveniles, 1150 to 38000 ind. $\mathrm{m}^{-2}, 1 \mathrm{yr}$ old subadults, 580 to 18000 ind. $\mathrm{m}^{-2}$ ). Growth was strongly negatively density-dependent for both juveniles and subadults. We then used sediment of low organic content (loss on ignition $3.7 \%$ ) to test whether the density-dependence of growth was due to a direct crowding effect at high density, or mainly due to food limitation. Using an intermediate amphipod density $\left(2800\right.$ ind. $\left.\mathrm{m}^{-2}\right)$ expected to give clear growth depression, we added baker's yeast as supplementary food at 6 levels corresponding to an input of 0 (control) to $147 \mathrm{~g} \mathrm{C} \mathrm{m}^{-2}$ over an $8 \mathrm{wk}$ period. The 3 highest yeast additions resulted in black, reduced sediment and elevated amphipod mortality in some replicates, but where the sediment did not become reduced, food additions enhanced growth significantly, demonstrating that growth depression at high density was primarily due to food limitation and not to crowding as such.
\end{abstract}

KEY WORDS: Baltic Sea $\cdot$ Deposit-feeder $\cdot$ Macrobenthos $\cdot$ Food limitation $\cdot$ Intraspecific competition $\cdot$ Monoporeia affinis

\section{INTRODUCTION}

It is often taken more or less for granted that the biomass of benthic macrofauna that can be supported on a given area of subtidal soft sediment is limited primarily by the amount of food available (e.g. Pearson \& Rosenberg 1987, Josefson 1998). This idea is consistent with the large-scale distribution of soft-bottom benthos, such as the decrease in biomass with increasing depth and consequently lower availability of organic matter from the continental shelf, down the continental slope, to abyssal depths (Rowe 1971, Thiel 1983). Obvious exceptions occur, such as macrotidal continental shelves and exposed shallow sandy bottoms, where

\footnotetext{
*E-mail: ragnar_e@system.ecology.su.se

**Present address: Pl. 52053 Starbo, 75263 Uppsala, Sweden
}

regular or intermittent turbulence, strong enough to sweep away, bury or kill animals, is a limiting factor (e.g. Rees et al. 1977). In some shallow areas, predation limits macrobenthic biomass (Blegvad 1928, Virnstein 1977, Reise 1985). The initial response of macrobenthos to organic enrichment is often an increase in biomass, until excessive oxygen consumption leads to anoxia and eventual elimination of the macrobenthos (Pearson \& Rosenberg 1978). This also supports the idea of benthic food limitation as the norm and other limiting factors as being rather the exception (Pearson \& Rosenberg 1987).

If the biomass of the whole macrobenthic community is food-limited, then some populations of deposit-feeding animal populations must also be food-limited. If other deposit-feeding populations are limited by predation, by abiotic factors, or by interference competi- 
tion, then the food resources they leave unused should increase the biomass of the food-limited populations. Levinton (1972) suggested that competition for food should be more common in deposit-feeders than in suspension-feeders, yet there are few experimental demonstrations of food limitation in benthic depositfeeders. The few experimental demonstrations of competition in marine deposit-feeding populations reported in reviews by Connell (1983), Schoener (1983) and Branch (1984) concerned animals that feed primarily on benthic microalgae, and either did not demonstrate the competitive mechanism or indicated that interference competition was involved. Careful laboratory studies have demonstrated food limitation in the opportunistic polychaete Capitella capitata (Chesney \& Tenore 1985, Tenore \& Chesney 1985). Kamermans et al. (1992) reported density-dependent growth in a deposit-feeding bivalve population in an outdoor flow-through basin, and concluded that the cause was intraspecific competition for sedimentary food. Even when field data clearly show individual growth rates to decrease as population density increases, experimental evidence is needed to demonstrate if this is due to food limitation or is a crowding effect, because of intraspecific interference competition in a dense population (e.g. Miralto et al. 1996, Wheatcroft et al. 1998).

In the Baltic Sea, where tides are negligible, benthic biomass increases steeply from the oligotrophic northernmost end to the much more productive southwestern end (Elmgren 1978). Food is thought to regulate individual growth rate and thus population biomass in the most abundant deposit-feeder in the Baltic Sea, the amphipod Monoporeia affinis (Lindström) (syn. Pontoporeia affinis: see Bousfield 1989). Its individual growth rate peaks after the sinking spring diatom bloom has enriched the sediment with high-quality organic matter (Cederwall 1977, Elmgren 1978, Lehtonen \& Andersin 1998). Sarvala (1986) and Leonardsson (1994) noted a negative density-dependence of growth in Baltic Sea populations of M. affinis, and Johnson (1987) reported similar results for a Swedish lake population. In lakes with good feeding conditions, its growth is rapid and its life cycle shortened from the normal 2 yr to 1 yr (Wiederholm 1973, Johnson 1987). Temperature also seems to affect the length of its life cycle, since 1 yr life cycles are common in the warmer, shallower areas, even where deeper populations have life cycles of 2 or 3 yr (Segerstråle 1950, Ankar \& Elmgren 1976). Uitto \& Sarvala (1991) argued that $M$. affinis derives most of its energy from sediment organic matter, not from micro-organisms or meiofauna, and that field populations are likely to be strictly food-limited. Studies of the annual dynamics of lipid reserves in M. affinis support this interpretation (Hill et al. 1992,
Lehtonen \& Andersin 1998). Field evidence thus suggests that food limitation, and consequent intraspecific competition for food, regulates the dense $M$. affinis populations that are common in the Baltic Sea. Yet it is hard from field data to rule out the influence of a possible natural growth periodicity or of direct crowding effects, rather than food limitation, as explanations for the patterns described. We here report laboratory experiments that test the hypotheses that: (1) growth of $M$. affinis is negatively density-dependent; (2) the reduced growth at high population density is due to food limitation.

\section{MATERIALS AND METHODS}

Study area. Experiments were carried out in 1982 at the Askö Laboratory, NW Baltic proper $\left(58^{\circ} 49^{\prime} \mathrm{N}\right.$, $17^{\circ} 38^{\prime} \mathrm{E}$ ). In this brackish-water area (salinity $=6$ to 7.5), Monoporeia affinis (Lindström) is an important species in the macrobenthos below a depth of about $20 \mathrm{~m}$. It alone contributed almost half the abundance (on average 1640 ind. $\mathrm{m}^{-2}$ ), and a quarter of the shellfree dry biomass of macrobenthos in the 9 to $50 \mathrm{~m}$ depth zone in 1971 (Ankar \& Elmgren 1976), and 8 to $16 \%$ of the shell-free dry biomass in 1982 to 1994 (Cederwall 1999). The situation is similar over large areas of the Baltic Sea (Rumohr et al. 1996). Further north, $M$. affinis forms dense and almost monospecific communities over large areas (Hessle 1924, Ankar 1977, Elmgren et al. 1984, Sparrevik \& Leonardsson 1999). Elmgren et al. (1984) found average densities in the Bothnian Sea of 1900 ind. $\mathrm{m}^{-2}$ (plus 4000 juveniles $\mathrm{m}^{-2}$ in the meiofauna fraction), and numbers as high as 23400 ind. $\mathrm{m}^{-2}$ in the Gulf of Bothnia (Leonardsson et al. 1988) and 27600 ind. $\mathrm{m}^{-2}$ in the Gulf of Finland (Sarvala 1986) have been recorded.

Experimental system. Small experimental jars (vol. = 21 , sediment area $=104 \mathrm{~cm}^{2}$ : see Fig. 1 in Elmgren et al. 1986) were supplied with seawater pumped from $16 \mathrm{~m}$ depth at a flow rate of $0.9 \pm 0.1 \mathrm{l} \mathrm{h}^{-1}($ mean \pm SEM) and filtered through a $90 \mu \mathrm{m}$ plankton net. The experimental water temperature was $6 \pm 2{ }^{\circ} \mathrm{C}(\mathrm{n}=31)$ and the salinity $6.7 \pm 0.1(\mathrm{n}=5)$ compared to field values of $4 \pm$ $1^{\circ} \mathrm{C}$ and $7.2 \pm 0.1$ at $30 \mathrm{~m}$ depth during the same period ( $\mathrm{n}=9$ in both cases; Larsson \& Johansson 1984). A dim green light simulated roughly the ambient light at $30 \mathrm{~m}$ depth, with natural day-length regulated automatically by an outdoor photocell.

Sediments were collected with a van Veen grab from sites with Monoporeia affinis, sieved through a $300 \mu \mathrm{m}$ sieve to remove macrofauna and homogenised. Water content was determined after drying overnight at $105^{\circ} \mathrm{C}$, and loss on ignition (LOI) after $2 \mathrm{~h}$ at $500^{\circ} \mathrm{C}$. Amphipods were collected with a dredge at 30 to $50 \mathrm{~m}$ 
depth, gently sieved out with cold seawater, and quickly sorted into batches of 25 (juvenile and subadult density-dependence experiments) or 5 (subadult food-limitation experiment), keeping temperature low at all times. Before the experiments, juveniles were kept for $\leq 3 \mathrm{~d}$ and subadults for $\leq 16 \mathrm{~d}$ (food-limitation experiment $\leq 2 \mathrm{~d}$ ) in natural sediment in the same room and conditions as during the experiments. Each jar received $560 \mathrm{ml}$ of sediment slurry, giving a sediment depth of $\sim 6 \mathrm{~cm}$ after settling. After 12 to $24 \mathrm{~h}$, amphipods were added in haphazardly selected batches. Batches preserved at once in $10 \%$ formalin buffered with hexamethylenetetramine gave estimates of initial amphipod length and dry mass $\left(60^{\circ} \mathrm{C}\right.$, after several months in formalin). Jars were placed randomly in the experiment room to minimise differences in light, temperature, and flow among treatments. The water leaving 8 jars per experiment was led to an additional, empty $3 \mathrm{l}$ jar, to estimate the loss of sediments with the outflow during the experiment. At the end of the experiments the content of these outflow jars was filtered through Whatman GF/F filters (nominal pore size $0.8 \mu \mathrm{m}$ ) and analysed for sediment wet mass and amphipod presence.

At the end of the experiments, amphipods were recovered by sieving through a $1 \mathrm{~mm}$ net, followed by a $0.5 \mathrm{~mm}$ net in the experiment with juveniles, and were preserved as above. Length from the tip of the rostrum to the end of the last urosome segment was measured on straightened-out amphipods under a stereo microscope. Dry mass, including gut content, was measured to the nearest $0.01 \mathrm{mg}$. In each jar, a sediment core of $25 \mathrm{~mm}$ inner diameter was taken to $2 \mathrm{~cm}$ depth and analysed for LOI.

Experimental design. Tests of density-dependence of growth rates: The sediment was collected on March 29 , before the spring phytoplankton bloom, from a $30 \mathrm{~m}$-deep inshore station. It had high water content $(80 \pm 5 \% ; \mathrm{n}=2)$ and LOI $(10.9 \pm 0.3 \% ; \mathrm{n}=2)$ after sieving. Juvenile treatments had from 12 to 400 Monoporeia affinis young-of-the-year $\mathrm{jar}^{-1}$, corresponding to a density of about 1150 to 38000 ind. $\mathrm{m}^{-2}$ (details in Table 1). Handling large numbers of small juveniles takes time. The experiment with juveniles was therefore started over several days, with 1 (March 30, 31, April 1,5) or 2 (April 2) replicates per treatment each day, and ended over 2 d (June 2: 100, 200 and 400 ind. jar $^{-1}$ treatments; June 3: 12, 25 and 50 ind. jar ${ }^{-1}$ treatments). Subadult treatments had from 6 to $2001 \mathrm{yr}$ old M. affinis jar ${ }^{-1}$ and ran from 14 April to 9 June (details in Table 2). Outflow jars were connected to juvenile 12, 100 and 400 ind. jar $^{-1}$ treatments and to subadult 6, 50 and 100 ind. jar $^{-1}$ treatments.

Test of food limitation of subadult growth rate: This experiment ran from April 7 to June 8, using sediment collected on March 29 from a 45 m-deep offshore sta-

Table 1. Monoporeia affinis and Pontoporeia femorata. Test of density-dependence of growth rate in juveniles (mean \pm SEM). Initial numbers estimated from preserved batches, except for the 12 ind. jar ${ }^{-1}$ treatment, to which amphipods were added individually, excluding all $P$. femorata. Initial length: all amphipods $=1.52 \pm 0.06 \mathrm{~mm}$. M. affinis $=1.42 \pm 0.01 \mathrm{~mm} ;$. femorata $=$ $1.67 \pm 0.03 \mathrm{~mm}$. Initial individual amphipod dry mass $=0.010 \pm 0.001 \mathrm{mg}$. Average experiment duration was $62 \mathrm{~d}$. $\mathrm{n}$ : number of replicates, $\Delta$ : changes in length and mass

\begin{tabular}{|c|c|c|c|c|c|c|}
\hline & \multicolumn{6}{|c|}{ Treatment (intended no. of ind. $\mathrm{jar}^{-1}$ ) } \\
\hline & 12 & 25 & 50 & 100 & 200 & 400 \\
\hline \multicolumn{7}{|l|}{ All amphipods } \\
\hline Initial number of ind. jar $^{-1}$ & 12 & $24.8 \pm 0.3$ & $49.5 \pm 0.6$ & $99 \pm 1$ & $198 \pm 3$ & $396 \pm 5$ \\
\hline Initial number of ind. $\mathrm{m}^{-2}$ & 1150 & 2375 & 4750 & 9500 & 19000 & 38000 \\
\hline Final number of ind. jar ${ }^{-1}$ & $7 \pm 1$ & $19 \pm 1$ & $35 \pm 3$ & $65 \pm 8$ & $149 \pm 6$ & $109 \pm 38$ \\
\hline$\%$ survival & $58 \pm 8$ & $73 \pm 6$ & $73 \pm 7$ & $67 \pm 8$ & $78 \pm 2$ & $26 \pm 11$ \\
\hline Final ind. dry mass (mg) & $0.20 \pm 0.01$ & $0.22 \pm 0.02$ & $0.14 \pm 0.01$ & $0.11 \pm 0.01$ & $0.06 \pm 0.01$ & $0.05 \pm 0.01$ \\
\hline$\Delta$ individual dry mass (mg) & 0.19 & 0.21 & 0.13 & 0.10 & 0.05 & 0.04 \\
\hline$\Delta$ final dry biomass $(\mathrm{mg})$ & 1.3 & 3.9 & 4.4 & 5.6 & 5.5 & 0.4 \\
\hline \multicolumn{7}{|l|}{ Monoporeia affinis } \\
\hline Initial number of ind. jar ${ }^{-1}$ & 12 & $24 \pm 1$ & $47 \pm 2$ & $94 \pm 3$ & $188 \pm 6$ & $376 \pm 12$ \\
\hline Final number of ind. jar ${ }^{-1}$ & $7.2 \pm 0.9$ & $19 \pm 1$ & $32 \pm 3$ & $62 \pm 7$ & $143 \pm 5$ & $107 \pm 38$ \\
\hline Final length (mm) & $3.9 \pm 0.1$ & $3.9 \pm 0.1$ & $3.6 \pm 0.1$ & $3.2 \pm 0.1$ & $2.8 \pm 0.1$ & $2.7 \pm 0.1$ \\
\hline$\Delta$ length $(\mathrm{mm})$ & $2.5 \pm 0.1$ & $2.5 \pm 0.1$ & $2.2 \pm 0.1$ & $1.8 \pm 0.1$ & $1.4 \pm 0.1$ & $1.3 \pm 0.1$ \\
\hline \multicolumn{7}{|l|}{ Pontoporeia femorata } \\
\hline Initial number of ind. jar ${ }^{-1}$ & 0 & $1.2 \pm 0.8$ & $2.5 \pm 1.6$ & $5 \pm 3$ & $10 \pm 6$ & $20 \pm 13$ \\
\hline Final number of ind. $\mathrm{jar}^{-1}$ & 0 & 0 & $2.8 \pm 1.2$ & $4 \pm 2$ & $6 \pm 2$ & $2 \pm 1$ \\
\hline Final length (mm) & - & - & $2.6 \pm 0.1$ & $2.4 \pm 0.1$ & $2.3 \pm 0.1$ & $2.3 \pm 0.2$ \\
\hline$\Delta$ length $(\mathrm{mm})$ & - & - & $0.9 \pm 0.1$ & $0.6 \pm 0.1$ & $0.7 \pm 0.1$ & $0.6 \pm 0.1$ \\
\hline $\mathrm{n}$ & 6 & 6 & 6 & 6 & 6 & 6 \\
\hline
\end{tabular}


Table 2. Monoporeia affinis. Test of density-dependence of subadult growth rate (mean \pm SEM); initial amphipod length $=6.0 \pm$ $0.1 \mathrm{~mm}$; initial individual amphipod dry mass $=0.51 \pm 0.05 \mathrm{mg}$. Experiment duration was $57 \mathrm{~d}$. (n): number of replicates; $\Delta$ : changes in length and mass

\begin{tabular}{|c|c|c|c|c|c|c|}
\hline & \multicolumn{6}{|c|}{ Treatment (intended no. of ind. $\mathrm{jar}^{-1}$ ) } \\
\hline & 6 & 12 & 25 & 50 & 100 & 200 \\
\hline Initial number of ind. $\mathrm{jar}^{-1}$ & 6 & 12 & $24 \pm 1$ & $47 \pm 2$ & $94 \pm 3$ & $189 \pm 6$ \\
\hline Initial number of ind. $\mathrm{m}^{-2}$ & 580 & 1150 & 2300 & 4500 & 9000 & 18000 \\
\hline Final number of ind. jar ${ }^{-1}$ & $4.8 \pm 0.4$ & $9.2 \pm 0.5$ & $21 \pm 1$ & $38 \pm 1$ & $78 \pm 4$ & $157 \pm 7$ \\
\hline$\%$ survival & 80 & 77 & 91 & 81 & 83 & 83 \\
\hline Final length (mm) & $7.3 \pm 0.2$ & $7.1 \pm 0.1$ & $7.0 \pm 0.1$ & $6.7 \pm 0.1$ & $6.5 \pm 0.1$ & $6.4 \pm 0.1$ \\
\hline$\Delta$ length $(\mathrm{mm})$ & $1.3 \pm 0.2$ & $1.1 \pm 0.1$ & $1.0 \pm 0.1$ & $0.7 \pm 0.1$ & $0.5 \pm 0.1$ & $0.4 \pm 0.1$ \\
\hline Final ind. dry mass (mg) & $1.40 \pm 0.09$ & $1.06 \pm 0.07$ & $1.02 \pm 0.05$ & $0.78 \pm 0.03$ & $0.77 \pm 0.06$ & $0.72 \pm 0.02$ \\
\hline$\Delta$ total dry biomass (mg) & 3.7 & 3.6 & 9.2 & 5.7 & 12 & 17 \\
\hline $\mathrm{n}$ & 5 & 5 & 5 & 5 & 5 & 5 \\
\hline
\end{tabular}

Table 3. Monoporeia affinis. Test of food limitation of subadult growth rate (mean \pm SEM). Initial abundance $=29.5 \pm 0.4$ ind. jar ${ }^{-1}$ or 2800 ind. $\mathrm{m}^{-2}$; initial length $=6.6 \pm 0.1 \mathrm{~mm}$; initial dry mass $=0.94 \pm 0.11 \mathrm{mg}$. Experiment duration was $62 \mathrm{~d}$. (n): number of replicates; $\Delta$ : changes in length and mass

\begin{tabular}{|c|c|c|c|c|c|c|}
\hline & \multicolumn{6}{|c|}{ Treatment (yeast dose, $2 \times$ per week $[g]$ ) } \\
\hline & 0 & 0.05 & 0.1 & 0.2 & 0.4 & 0.8 \\
\hline$\sum$ yeast added $\left(\mathrm{g} \mathrm{C} \mathrm{m}^{-2}\right)$ & 0 & 9.2 & 18 & 37 & 74 & 147 \\
\hline Final number of ind. jar $^{-1}$ & $24 \pm 1$ & $25 \pm 1$ & $23 \pm 1$ & $19 \pm 4$ & $17 \pm 5$ & $10 \pm 4$ \\
\hline$\%$ survival & $80 \pm 3$ & $83 \pm 3$ & $77 \pm 3$ & $64 \pm 13$ & $57 \pm 16$ & $34 \pm 12$ \\
\hline Final length (mm) & $7.0 \pm 0.1$ & $7.3 \pm 0.1$ & $7.5 \pm 0.1$ & $7.5 \pm 0.1$ & $7.3 \pm 0.1$ & $7.7 \pm 0.2$ \\
\hline$\Delta$ length $(\mathrm{mm})$ & $0.4 \pm 0.1$ & $0.7 \pm 0.1$ & $0.9 \pm 0.1$ & $0.9 \pm 0.1$ & $0.8 \pm 0.1$ & $1.2 \pm 0.2$ \\
\hline Final ind. dry mass $\left(\mathrm{mg}^{\mathrm{d}}\right)$ & $1.0 \pm 0.1$ & $1.4 \pm 0.1$ & $1.4 \pm 0.1$ & $1.8 \pm 0.1$ & $1.2 \pm 0.1$ & $1.7 \pm 0.1$ \\
\hline$\Delta$ ind. dry mass (mg) & 0.1 & 0.5 & 0.5 & 0.9 & 0.3 & 0.8 \\
\hline$\Delta$ total dry biomass (mg) & -3.7 & 7.3 & 4.5 & 6.5 & -7.3 & -10.7 \\
\hline $\mathrm{n}$ & 6 & 6 & 6 & $6^{\mathrm{a}}$ & $6^{\mathrm{b}}$ & $6^{\mathrm{c}}$ \\
\hline
\end{tabular}

tion. After sieving, this clay-like sediment had a low water content $(55 \pm 1 \% ; \mathrm{n}=4)$ and LOI $(3.7 \% ; \mathrm{n}=1)$, indicating low organic content and nutritive value. The Monoporeia affinis density used corresponded to about 2800 ind. $\mathrm{m}^{-2}$ (details in Table 3). Starting on April 14, baker's yeast was added to the jars twice a week as supplementary food, in doses of 0 (control), 0.05, 0.1, $0.2,0.4$ and $0.8 \mathrm{~g}$ wet mass. A single yeast lot was divided into doses and deep-frozen until used. It had a water content of $74 \pm 1 \%(\mathrm{n}=6)$, and a dry content of $46 \pm 1 \% \mathrm{C}(\mathrm{n}=5), 7.9 \pm 0.2 \% \mathrm{~N}(\mathrm{n}=6)$ and $1.4 \pm 0.1 \% \mathrm{P}$ $(\mathrm{n}=3)$. Each dose was suspended in $10 \mathrm{ml}$ filtered seawater and injected near the bottom of the jar with a syringe, with the water flow turned off for $2 \mathrm{~h}$ after the addition to let the yeast settle. Each jar received 16 yeast additions, corresponding totally to 0 (control), $9,18,37,74$ and $147 \mathrm{~g} \mathrm{C} \mathrm{m}^{-2}$. Outflow jars were connected to jars receiving $0,0.1$ and $0.8 \mathrm{~g}$ yeast additions.

Statistical treatment. Statistical analyses were performed using 'Statistica '99' Edition, Statsoft Inc., Tulsa, OK, USA. Variance of homogeneity was tested with Cochran's or Bartlett's tests. Heterogeneous variances were removed through data transformation, as noted in individual cases below. Percentage values were arcsine-transformed before testing. When an analysis of variance was significant $(\mathrm{p}<0.05)$, multiple comparisons were made using the Tukey HSD test or the Tukey HSD test for unequal $n$.

\section{RESULTS}

\section{Test of density-dependence of juvenile growth rate}

The 400 ind. jar ${ }^{-1}$ treatment was excluded from all analyses (except outflow jars), since many amphipods were found in the outflow jars at termination, indicating failure of the plankton net. The water in the 400 ind. jar $^{-1}$ treatment was turbid, and swimming amphipods were seen all day, even though they normally swim only at night (Cederwall 1979, Lindström 1991). 
Because of the difficulty of assigning small amphipods to species without harming them, some Pontoporeia femorata were inadvertently used in the experiment (except the 12 ind. jar ${ }^{-1}$ treatment, see Table 1). The fraction of $P$. femorata was $\sim 5 \%$ initially (estimated from preserved batches), and $4 \%$ among the survivors, with no significant variation among the treatments (data arcsine-transformed, ANOVA, $F_{2,15}=$ $0.14, \mathrm{p}=0.87)$.

There were no significant differences in sediment LOI among treatments at the end of the experiment, (data arcsine-transformed, ANOVA, $F_{3,16}=0.18, \mathrm{p}=$ $0.91)$. Sediment accumulation in outflow jars was small ( $0.01 \%$ of initial sediment in experimental jar), and did not differ significantly among treatments (ANOVA, $F_{2,4}=0.60, \mathrm{p}=0.59$ ).

Mean amphipod survival was 58 to $78 \%$, with no significant difference among the treatments, either for total amphipods (data arcsine-transformed, ANOVA, $F_{4,25}=1.08, \mathrm{p}=0.39$ ) or for the individual species (ANOVA; Monoporeia affinis: data arcsine-transformed, $F_{4,25}=1.24, \mathrm{p}=0.32$; Pontoporeia femorata: data arcsine-transformed, $F_{2,15}=0.14, p=0.87$ ). Individual length increased in all treatments (Fig. 1) for both species (surviving $P$. femorata were found only in treatments with $\geq 50$ amphipods) and for pooled amphipods (ANOVA: $M$. affinis, data log-transformed, $F_{5,30}=363, \mathrm{p}<0.001$, Tukey's test, $\mathrm{p}<0.05 ;$ P. femorata, $F_{4,15}=13.52, \mathrm{p}<0.001$, Tukey's test for unequal $n, \mathrm{p}<$ 0.05 ; pooled: $F_{5,30}=123, \mathrm{p}<0.001$, Tukey's test, $\mathrm{p}<$ $0.05)$.

Mean individual mass gain was measured on pooled amphipods, and was significant during the experiment for all treatments (log-transformed values, ANOVA, $F_{5,26}=97.4, \mathrm{p}<0.001$; Tukey's test for unequal $n, \mathrm{p}<$ $0.05)$. Final individual mass was greatest in the 12 and 25 ind. jar ${ }^{-1}$ treatments, and declined at higher densities, being negatively correlated to initial density $(\mathrm{r}=$ $-0.79, \mathrm{n}=30$ ). Total population mass gain peaked in the 100 ind. jar $^{-1}$ treatment. Growth in length was greatest in the 12 and 25 ind. jar $^{-1}$ treatments for Monoporeia affinis, and in the 50 ind. jar $^{-1}$ treatment for Pontoporeia femorata (absent in the 12 and 25 ind. $\mathrm{jar}^{-1}$ treatments), and was negatively correlated to initial density (all amphipods, $\mathrm{r}=-0.89, \mathrm{n}=30$ ). Individual $M$. affinis juveniles grew better than $P$. femorata juveniles at all densities, and ended up longer, even though they started out shorter.

\section{Test of density-dependence of subadult growth rate}

Since this experiment had $<1 \%$ Pontoporeia femorata, this species can be ignored. There were no significant differences in sediment LOI among treatments at

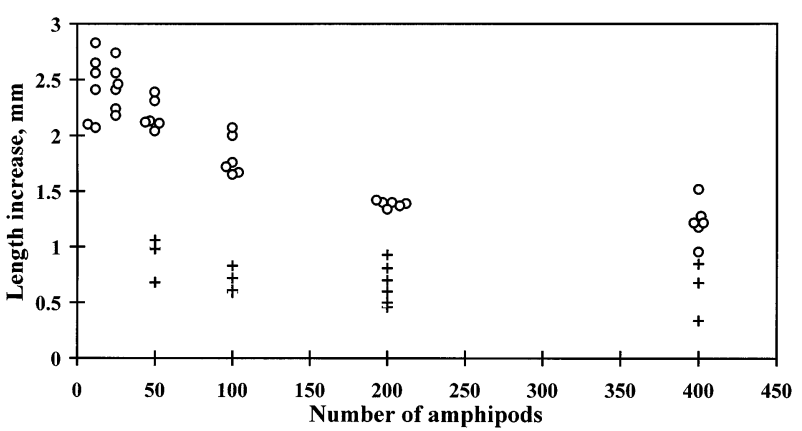

Fig. 1. Monoporeia affinis (০), and Pontoporeia femorata (+). Test of density-dependence of juvenile growth rate: increase in length of juveniles over $62 \mathrm{~d}$ as a function of initial amphipod density. To allow all data points to be seen, some overlapping points have been slightly displaced along $x$-axis

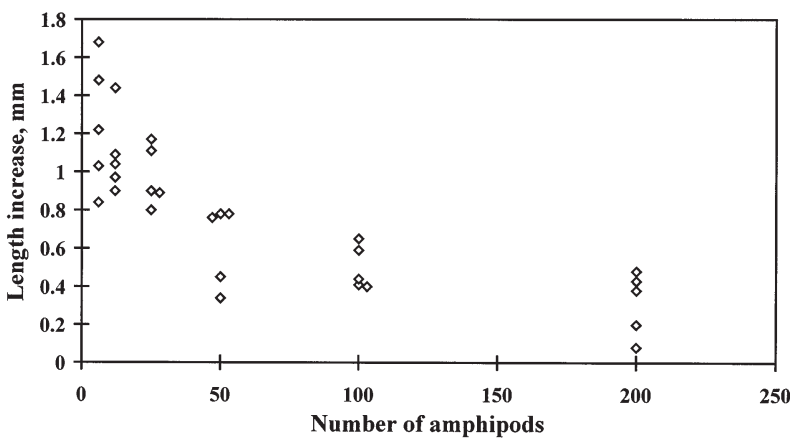

Fig. 2. Monoporeia affinis. Test of density-dependence of subadult growth rate. Increase in length of subadult amphipods over $57 \mathrm{~d}$ as a function of initial amphipod density. To allow all data points to be seen, some overlapping points have been slightly displaced along $x$-axis

the end of the experiment (data arcsine-transformed, ANOVA, $F_{3,6}=3.15, \mathrm{p}=0.11$ ). Little sediment accumulated in the outflow jars for the 6 ind. jar $^{-1}$ treatment ( $0.01 \%$ of initial sediment in experimental jar), significantly more in the 50 and 200 ind. jar $^{-1}$ treatments (ANOVA, $F_{3,6}=339 \mathrm{p}<0.001$; Tukey's test for unequal $n, \mathrm{p}<0.05)(\sim 0.1$ and $0.5 \%$ of initial sediment, respectively).

Mean amphipod survival was 77 to $91 \%$, with no significant difference among treatments (data arcsinetransformed, ANOVA, $F_{5,24}=1.03, \mathrm{p}=0.42$ ). Individual amphipod length increased significantly in all but the 200 ind. jar ${ }^{-1}$ treatment (Fig. 2, ANOVA, $F_{6,28}=21.0$, $\mathrm{p}<0.001$; Tukey's test, $\mathrm{p}<0.05$ ), but always proportionally less than for juveniles at the same density. Individual amphipod mass increased significantly in the 3 lowest densities (ANOVA, $F_{6,27}=23.7, \mathrm{p}<0.001$, Tukey's test for unequal $n, \mathrm{p}<0.05)$. Both final length $(\mathrm{r}=-0.78 ; \mathrm{n}=30)$ and final mass $(\mathrm{r}=-0.64, \mathrm{n}=29)$ were negatively correlated with initial density. 


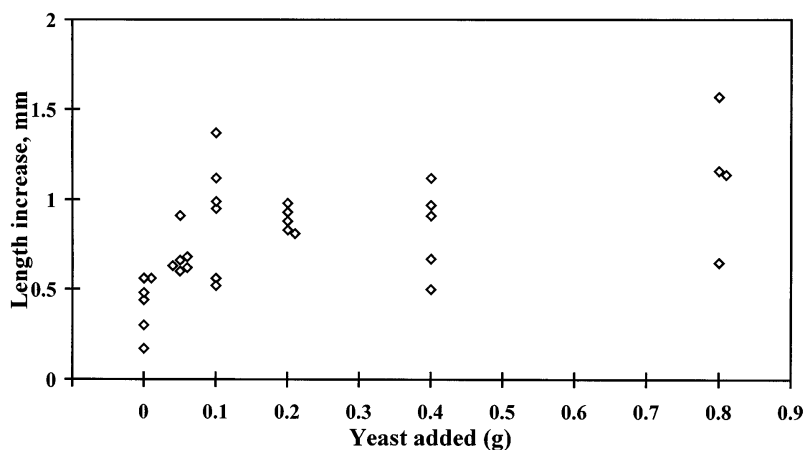

Fig. 3. Monoporeia affinis. Test of food limitation of subadult growth rate. Increase in length of subadult amphipods over $62 \mathrm{~d}$ as a function of amount of baker's yeast added. To allow all data points to be seen, some overlapping points have been slightly displaced along $x$-axis

\section{Test of food limitation of subadult growth rate}

No Pontoporeia femorata were found in this experiment. There were no significant differences in sediment LOI among treatments at termination (data arcsine-transformed, ANOVA, $F_{3,4}=6.42, \mathrm{p}=0.052$ ). Sediment accumulation in outflow jars was small $(\sim 0.05 \%$ of initial sediment in experimental jar) and did not differ significantly among the treatments (ANOVA, $F_{3,6}=2.12, \mathrm{p}=0.20$ ).

Mean amphipod survival was 34 to $83 \%$ (Table 3 ), and significantly lower at additions of $0.8 \mathrm{~g}$ yeast than in the control and the 2 lowest levels of addition (ANOVA, $F_{5,30}$ $=3.46, \mathrm{p}=0.014 ;$ Tukey's test, $\mathrm{p}<0.05)$. Most jars with $0.8 \mathrm{~g}$ additions and some with 0.4 and $0.2 \mathrm{~g}$ additions developed black, reduced patches on the sediment surface, and had high amphipod mortalities. When such jars were excluded, no significant difference in survival among treatments remained (ANOVA, $F_{4,21}=2.13, \mathrm{p}=$ 0.11 ), and mean survival was 77 to $89 \%$.

Amphipod length and mass both increased significantly during the experiment in all treatments (Fig. 3) except the controls (length: log-transformed data, ANOVA, $F_{6,29}=12.0, \mathrm{p}<0.001$; Tukey's test for unequal $n, \mathrm{p}<0.05$; individual mass: $F_{6,28}=11.4, \mathrm{p}<$ 0.001 ; Tukey's test for unequal $n, \mathrm{p}<0.05)$. Growth was positively correlated with the amount of yeast added (length: log-transformed data, $\mathrm{r}=0.54, \mathrm{n}=32$; mass: $\mathrm{r}=$ $0.45, \mathrm{n}=31$ ).

\section{DISCUSSION}

\section{Tests of density-dependence of growth rates}

The experiments confirmed a strong density-dependence for growth, but not for survival, in both juvenile and subadult Monoporeia affinis. The span of growth rates in the experiment covered that of field populations of the same age in Cederwall's (1977) study, but was somewhat lower at equivalent population densities, especially when the presence of 3 age classes in the field is considered. Hill (1992) showed experimentally that juvenile growth rate in $M$. affinis is densitydependent and is reduced in the presence of $1 \mathrm{yr}$ old subadults. Hill also found that mortality increased in the high-density treatments after $3 \mathrm{mo}$, and that this mortality slowed the body-mass loss of survivors, presumably since the dead individuals served as food. Goedkoop \& Johnson (1994) reported that growth of juvenile $M$. affinis was strongly density-dependent in freshwater also, but found no effect on survival after $43 \mathrm{~d}$.

The experiment on juvenile growth inadvertently included some individuals of the similar amphipod Pontoporeia femorata. They were too few in number $(\leq 5 \%)$ to be likely to have influenced the results for Monoporeia affinis, but the interspecific negative effect of $M$. affinis on the growth of $P$. femorata was significant. As in the field (Cederwall 1977), we found that juvenile growth was slower in $P$. femorata than in $M$. affinis. This is not surprising, given the lower rates of ingestion (Lopez \& Elmgren 1989) and metabolism (Cederwall 1979) of $P$. femorata. The experimental salinity was, however, near the lower salinity limit for $P$. femorata, as judged from its field distribution (Segerstråle 1950, Järvekülg 1973). In the Askö area, $P$. femorata is normally found below $\sim 30 \mathrm{~m}$ depth, at a salinity about 0.5 higher than in our experiment, where its slow growth may have been partly an effect of low salinity.

Apparent mortality was high in the 400 ind. jar $^{-1}$ treatment of the juvenile growth experiment, but outflow jars showed that much of this was in fact an artefact, as juveniles had escaped through the $90 \mu \mathrm{m}$ net. Outflow jars for other treatments showed no escape through the net. The daytime swimming and constantly turbid water in the 400 ind. jar $^{-1}$ treatment suggested that amphipods were trying to escape, seemingly in direct response to the high density of conspecifics rather than in response to lower food quality, since the initial food quality was the same in all treatments. Ambrose (1986) likewise interpreted densitydependent emigration by a deposit-feeding amphipod as arising from avoidance of competing individuals. Donner et al. (1987) reported field observations of increased swimming by Monoporeia affinis as feeding conditions deteriorated in late summer, suggesting that food shortage can also cause emigration from the sediment. $M$. affinis has been reported to swim away from unfavourable conditions, such as the presence of toxic contaminants (Lindström \& Lindström 1980), low 
oxygen (Johansson 1997) and predator presence (Ejdung 1998, Sparrevik \& Leonardsson 1999).

Amphipod mortality during the experiment was mostly 9 to $27 \%$, but reached over $40 \%$ in some treatments. At most, this added $\sim 25 \mathrm{mg}$ of organic matter to sediment already containing 15 to $25 \mathrm{~g}$ of organic matter, a small addition to the total organic carbon store available to the amphipods. The highest individual amphipod biomass gains were not found in the treatments with the highest mortality. The highest total amphipod biomass gain (final minus initial biomass) was only $\sim 18 \mathrm{mg}$ dry mass (subadult growth rate, 200 ind. jar $^{-1}$ treatment), indicating utilisation of only a minute part of the total sediment store of organic material. This suggests that most of the organic matter in the sediment was of low quality (cf. Levinton \& Stewart 1988), and that organic matter from dead amphipods may have improved the quality of food for the survivors, as assumed by Hill (1992). Since the percent mortality rate did not differ between treatments, the high-density treatments received most of this inadvertent enrichment of the sediment, without which differences in individual growth rate between high- and low-density treatments would probably have been somewhat greater.

\section{Test of food limitation of subadult growth rate}

The use of baker's yeast as supplementary food can be criticised, since it is not a natural food item for these amphipods and it is not known whether they possess the enzymes to break it down. Baker's yeast has, however, been found to constitute an excellent food in other crustacean growth experiments, in which it was selected as a readily available non-toxic micro-organism that lacked a hard, protective cell wall (Coutteau et al. 1992). Since our intention was to study if supplementary food could reduce or eliminate the densitydependence of growth in Monoporeia affinis, it was not necessary for the added food to be of the very highest quality. Our results prove that yeast can be assimilated by the amphipods, either directly or after initial processing by sediment microbiota.

The test of food limitation of growth rate showed clearly that supplemental feeding could counteract the negative effect of a relatively high density of subadults. This experiment used sediment of low organic content, and daily growth in length in the control was as low as for 200 ind. $\mathrm{jar}^{-1}$ in the subadult densitydependence experiment, which used sediment of higher organic content. By adding $0.2 \mathrm{~g}$ of yeast twice a week, a higher growth rate, falling between those obtained for 25 and 50 ind. jar $^{-1}$ in the subadult density-dependence experiment, was achieved. Still higher yeast additions caused reduced sediments and greatly increased mortality, making it difficult to evaluate changes in growth, since mortality may have been size-selective. We do not know why only some replicates receiving high yeast additions developed reduced sediments, but suspect the cause may be related to small initial differences in water flow, settling of yeast and amphipod activity among individual jars. Even the lowest addition added about as much organic matter $\left(9 \mathrm{~g} \mathrm{C} \mathrm{m}^{-2}\right)$ as would be expected from a normal spring bloom. Larsson et al. (1986) reported sedimentation of $4.9 \mathrm{~g} \mathrm{C} \mathrm{m}^{-2}$ during a spring bloom event near the Askö Laboratory, while Graf et al. (1982) recorded $11.5 \mathrm{~g} \mathrm{C} \mathrm{m}^{-2}$ over 4 wk of a spring bloom in Kiel Bight, SW Baltic Sea. The higher yeast additions correspond more to local accumulations of detritus, which can be very patchy in the field.

\section{Conclusions}

Individual growth rate decreased with increasing amphipod density for juvenile and subadult Monoporeia affinis as well as for juvenile Pontoporeia femorata, confirming interpretations of field growth data that indicate that food limitation is common for Baltic Sea deposit-feeding benthic amphipods of the species $M$. affinis and $P$. femorata. This was true even though the greater number of amphipods dying at higher density added more organic matter to the sediment in those treatments. Our results thus confirm the densitydependence of growth in $M$. affinis, inferred from field experiments and shown for juveniles in the laboratory by Hill (1992) and Goedkoop \& Johnson (1994), and extend the results to subadults and to interspecific effects on juveniles of the co-occurring amphipod $P$. femorata.

Crowding can have dramatic negative effects on growth, even in the presence of abundant food (Miralto et al. 1996, Wheatcroft et al. 1998). Our results for Monoporeia affinis show that supplemental feeding can largely eliminate the growth reduction at high density. Hence, shortage of food explains most of the negative density-dependence of individual growth noted in field studies, even if some contribution from crowding cannot be ruled out, particularly between year-classes, which we did not test for (cf. Hill 1992). We can thus conclude that the most abundant species of deposit-feeding macrofauna in the Baltic Sea is primarily limited by food, not by interspecific interference effects

Acknowledgements. We thank the staff and director of the Askö Laboratory for good facilities and much help, and C. Savage and 4 anonymous referees for helpful comments. This 
study was supported by grants from the Swedish Natural Science Research Council to R.E., and from the Swedish Environment Protection Agency to S.A.

\section{LITERATURE CITED}

Ambrose WG (1986) Experimental analysis of the densitydependent emigration of the amphipod Rhepoxynius abronius. Mar Behav Physiol 12:209-216

Ankar S (1977) The soft bottom ecosystem of the northern Baltic proper, with special reference to the macrofauna. Contrib Askö Lab Univ Stockholm 19:1-62

Ankar S, Elmgren R (1976) The benthic macro- and meiofauna of the Askö-Landsort area-a stratified random sampling survey. Contrib Askö Lab Univ Stockholm 11: $1-115$

Blegvad H (1928) Quantitative investigations of bottom invertebrates in the Limfjord, 1910-1927, with special reference to the plaice food. Rep Dan Biol Stn 34:33-52

Bousfield EL (1989) Revised morphological relationships within the amphipod genera Pontoporeia and Gammaracanthus and the 'glacial relict' significance of their postglacial distributions. Can J Fish Aquat Sci 46:1714-1725

Branch GM (1984) Competition between marine organisms: ecological and evolutionary implications. Oceanogr Mar Biol Annu Rev 22:429-593

Cederwall H (1977) Annual macrofauna production of a soft bottom in the northern Baltic proper. In: Keegan BF, Céidigh PÓ, Boaden PJS (eds) Biology of benthic organisms. Pergamon Press, Oxford, p 155-164

Cederwall H (1979) Diurnal oxygen consumption and activity of two Pontoporeia (Amphipoda, Crustacea) species. In: Naylor E, Hartnoll RG (eds) Cyclic phenomena in marine plants and animals. Pergamon Press, Oxford, p 309-316

Cederwall H (1999) Long-term changes: deep, soft bottoms. Östersjö '98. Swedish marine monitoring in the Baltic proper. Annual Report. Stockholm Marine Research Centre, Stockholm, p 11-14 (in Swedish)

Chesney EJ, Tenore KR (1985) Oscillations of laboratory populations of the polychaete Capitella capitata (type I): their cause and implications for natural populations. Mar Ecol Prog Ser 20:289-296

Connell JH (1983) On the prevalence and relative importance of interspecific competition. Am Nat 122:661-696

Coutteau P, Brendonck L, Lavens P, Sorgeloos P (1992) The use of manipulated baker's yeast as an algal substitute for the laboratory culture of Anostraca. Hydrobiologia 234: 25-32

Donner KO, Lindström A, Lindström M (1987) Seasonal variation in the vertical migration of Pontoporeia affinis (Crustacea, Amphipoda). Ann Zool Fenn 24:305-313

Ejdung G (1998) Behavioural responses to chemical cues of predation risk in a three-tropic-level Baltic Sea food chain. Mar Ecol Prog Ser 165:137-144

Elmgren R (1978) Structure and dynamics of Baltic benthos communities, with special reference to the relationship between macro- and meiofauna. Kiel Meeresforsch Sonderh 4:1-22

Elmgren R, Rosenberg R, Andersin AB, Evans S, Kangas $\mathrm{P}$, Lassig J, Leppäkoski E, Varmo R (1984) Benthic macroand meiofauna in the Gulf of Bothnia (northern Baltic). Finn Mar Res 250:3-18

Elmgren R, Ankar S, Marteleur B, Ejdung G (1986) Adult interference with postlarvae in soft sediments: the Pontoporeia-Macoma example. Ecology 67:827-836
Goedkoop W, Johnson RK (1994) Exploitation of sediment bacterial carbon by juveniles of the amphipod Monoporeia affinis. Freshw Biol 32:553-563

Graf G, Bengtsson W, Diesner U, Schulz R, Theede H (1982) Benthic response to sedimentation of a spring phytoplankton bloom: process and budget. Mar Biol 67:201-208

Hessle C (1924) Bottenboniteringar i inre Östersjön. Medd K LantbrStyr 250:1-52

Hill C (1992) Interactions between year classes in the benthic amphipod Monoporeia affinis: effects on juvenile survival and growth. Oecologia 91:157-162

Hill C, Quigley MA, Cavaletto JF, Gordon W (1992) Seasonal changes in lipid content and composition in the benthic amphipods Monoporeia affinis and Pontoporeia femorata. Limnol Oceanogr 37:1280-1289

Järvekülg A (1973) Distribution and ecology of local populations of benthic glacial relicts. Oikos (Suppl) 15:91-97

Johansson B (1997) Behavioural response to gradually declining oxygen concentration by Baltic Sea macrobenthic crustaceans. Mar Biol 129:71-78

Johnson RK (1987) The life history, production and food habits of Pontoporeia affinis Lindström (Crustacea: Amphipoda) in Lake Erken. Hydrobiologia 144:277-283

Josefson AB (1998) Resource limitation in marine soft sediment-differential effects of food and space in the association between the brittle star Amphiura filiformis and the bivalve Mysella bidentata. Hydrobiologia 376: 297-305

Kamermans P, van der Veer HW, Karczmarski L, Doeglas GW (1992) Competition in deposit- and suspension-feeding bivalves: experiments in controlled outdoor environments. J Exp Mar Biol Ecol 162:113-135

Larsson U, Johansson S (1984) Himmerfjärdsundersökningen. Forskningsrapport 1982. Rapport till SYVAB. Mimeo. Askö Laboratory, Stockholm University, Stockholm (Technical Report) (in Swedish)

Larsson U, Hobro R, Wulff F (1986) Dynamics of a phytoplankton spring bloom in a coastal area of the northern Baltic proper. Contrib Askö Lab Univ Stockholm 30:1-32

Lehtonen KK, Andersin AB (1998) Population dynamics, response to sedimentation and role in benthic metabolism of the amphipod Monoporeia affinis in an open-sea area of the northern Baltic Sea. Mar Ecol Prog Ser 168: $71-85$

Leonardsson K (1994) Multiple density dependence in two sub-populations of the amphipod Monoporeia affinis: a potential for alternative equilibria. Oecologia 97:26-34

Leonardsson K, Sörlin T, Samberg H (1988) Does Pontoporeia affinis Lindström (Amphipoda) optimize age at reproduction in the Gulf of Bothnia? Oikos 52:328-336

Levinton JS (1972) Stability and trophic structure in depositfeeding and suspension-feeding communities. Am Nat 106:472-486

Levinton JS, Stewart S (1988) Effect of sediment organics, detrital input, and temperature on demography, production, and body size of a deposit feeder. Mar Ecol Prog Ser 49:259-266

Lindström M (1991) Factors affecting the horizontal migration of the amphipod Pontoporeia affinis Lindström. I. Recording method and response to water currents. J Exp Mar Biol Ecol 150:149-162

Lindström M, Lindström A (1980) Changes in the swimming activity of Pontoporeia affinis (Crustacea, Amphipoda) after exposure to sublethal concentrations of phenol, 4-chlorophenol and styrene. Ann Zool Fenn 17:221-231

Lopez G, Elmgren R (1989) Feeding depths and organic absorption for the deposit-feeding benthic amphipods 
Pontoporeia affinis and P. femorata. Limnol Oceanogr 34: 982-991

Miralto A, Ianora A, Poulet SA, Romano G, Laabir M (1996) Is fecundity modified by crowding in the copepod Centropages typicus. J Plankton Res 18:1033-1040

Pearson TH, Rosenberg R (1978) Macrobenthic succession in relation to organic enrichment and pollution of the marine environment. Oceanogr Mar Biol Annu Rev 16:229-311

Pearson TH, Rosenberg R (1987) Feast and famine? Structuring factors in marine benthic communities. In: Gee JHR, Giller PS (eds) Organisation of communities past and present. 27th Symposium of the British Ecological Society, Aberystwyth 1986. Blackwell Science, Ltd, Oxford, p 375-395

Rees EIS, Nicolaidou A, Laskaridou P (1977) The effects of storms on the dynamics of shallow water benthic associations. In: Keegan BF, Céidigh PÓ, Boaden PJS (eds) Biology of benthic organisms. Pergamon Press Ltd, Oxford, p 465-474

Reise K (1985) Predator control in marine tidal sediments. In: Gibbs PE (ed) Proc 19th Eur Mar Biol Symp, Plymouth, UK, 16-21 September, 1984, University Press, Cambridge, p 311-321

Rowe GT (1971) Benthic biomass and surface productivity. In: Costlow JD (ed) Fertility of the sea Vol 2. Gordon and Breach, New York, p 441-454

Rumohr H, Bonsdorff E, Pearson TH (1996) Zoobenthic succession in Baltic sedimentary habitats. Arch Fish Mar Res $44: 179-214$

Sarvala J (1986) Interannual variation of growth and recruitment in Pontoporeia affinis (Lindström) (Crustacea:

Editorial responsibility: Otto Kinne (Editor),

Oldendorf/Luhe, Germany
Amphipoda) in relation to abundance fluctuations. J Exp Mar Biol Ecol 101:41-59

Schoener TW (1983) Field experiments on interspecific competition. Am Nat 122:240-285

Segerstråle SG (1950) The amphipods on the coast of Finland - some facts and problems. Comment Biol 10:1-28

Sparrevik E, Leonardsson K (1999) Direct and indirect effects of predation by Saduria entomon (Isopoda) on the sizestructure of Monoporeia affinis (Amphipoda). Oecologia 120:77-86

Tenore KR, Chesney EJ (1985) The effects of interaction of rate of food supply and population density on the bioenergetics of the opportunistic polychaete Capitella capitata (type I). Limnol Oceanogr 30:1188-1195

Thiel H (1983) Meiobenthos and nanobenthos of the deep sea. In: Rowe GT (ed) The sea, Vol 8. John Wiley \& Sons, New York, p 205-217

Uitto A, Sarvala J (1991) Seasonal growth of the benthic amphipods Pontoporeia affinis and P. femorata in a Baltic archipelago in relation to environmental factors. Mar Biol 111:237-246

Virnstein RW (1977) The importance of predation by crabs and fishes on benthic infauna in Cheaspeake Bay. Ecology 58:1199-1217

Wheatcroft RA, Starczak VR, Butman CA (1998) The impact of population abundance on the deposit-feeding rate of a cosmopolitan polychaete worm. Limnol Oceanogr 43: 1948-1953

Wiederholm T (1973) On the life cycle of Pontoporeia affinis (Crustacea Amphipoda) in Lake Mälaren. Zoon 1:147-151

Submitted: March 24, 2000; Accepted: August 8, 2000

Proofs received from author(s): December 4, 2000 